Agro-Science Journal of Tropical Agriculture, Food, Environment and Extension Volume 11 Number 2 May 2012 pp $1-8$

ISSNIIIY-7455

\title{
ECONOMIC EFFICIENCY OF MAIZE PRODUCTION IN YOLA NORTH LOCAL GOVERNMENT AREA OF ADAMAWA STATE, NIGERIA.
}

\author{
Taru, ${ }^{1}$ V.B., Lamba ${ }^{2}$ C., \& Jare $^{2}$ N. \\ ${ }^{1}$ Department of Agricultural Technology, Federal Polytechnic P.M.B. 35 Mubi Adamawa \\ State, Nigeria \\ ${ }^{2}$ Department of Agricultural Economics and Extension, Usmanu Danfodio University Sokoto, \\ Nigeria \\ Corresponding author's email: taruvivian@ahoo.com
}

\begin{abstract}
This paper presents empirical evidence on the input-output relationship and the efficiency of resource use in maize production in Yola North Local Government Area of Adamawa state. A simple random sampling technique was employed and 120 maize farmers were selected from a population of 364. Data were analyzed using regression model. The production function analysis in the form of Cobb-Douglass production function was found very suitable for the analysis hence was selected as the best fit. The results showed that three of the inputs namely, fertilizer, seed and land were statistically significant at $\rho<0.05$ and $85 \%$ of the variation in maize yield was accounted for by the inputs included in the model. Similarly, the efficiency ratio computed showed that land, seed and fertilizer had MVP/MFC ratio greater than unity implying that the inputs were underutilized and output could be increased by increasing the levels of their utilization. The elasticity of production was greater than 1.00 which implied increasing return to scale. Finally, the study observed that the problems faced by maize farmers were, financial constraints, poor land tenure system, inadequate fertilizer, unavailability of extension service and improved seed.
\end{abstract}

Key word: Elasticity, marginal value product, marginal factor cost, input-output.

\section{INTRODUCTION}

Agriculture was the most crucial sector of the Nigerian economy prior to the oil boom (Okunneye, et al., 1995). It used to provide about $70 \%$ of employment opportunities and of course about $60 \%$ of the non-oil exports for the country. Unfortunately, with the discovery of oil and era of oil boom in 1970s, agriculture had become neglected and left at the mercy of underresourced rural dwellers. The rural people that have since been supporting agricultural activities are left in underdeveloped conditions without good roads, portable drinking water, education, electricity, access to formal credit and modern equipment to mention but a few. These problems over the years have made agricultural activities increasingly unattractive, thereby declining the sector's contribution to the national economy. Food production has since fallen short of meeting the local demand thereby resulting in increased food import bill for the country (Okunneye, et al., 1995).

The aforementioned problems have now created serious threat to food security and national development, especially as the problems tend to encourage rural-urban migration and its attendant congestion and increased crimes in urban areas of the country. These coupled with the rapid increase in population further tend to create starvation and hunger.

Maize is one of the staple crops, which have the potential for pulling the country out of the present food deficit. According to Adepoju (2006), maize is the highest yielding farm crop with multiple uses for food and industrial purposes. It is one of the most important crops in Nigeria which are used as raw materials in bakeries and confectioneries, in making baby foods, food thickening agents, brewing, oil production and beverages. Maize has been in the diet of Nigerians for centuries. Maize is the third most important cereal crop after sorghum and millet (Ojo, 2000). The cultivation of maize was formerly for subsistence purpose, but it has gradually become an important commercial crop on which many agro-allied industries depend for their raw materials (Iken and Amusa, 2004). The 
total land area (1000 HA) planted to maize in Nigeria in 2008, 2009, 2010, 2011 and 2012 was 4700, 4900, 5000, 5150 and 5200, respectively, with a growth rate of $17.50 \%, 4.265,2.04 \%$, $3.00 \%$ and $0.97 \%$, respectively. The output of maize (1000 MT) in Nigeria in 2008, 2009, 2010, 2011 and 2012 was 7970, 8950, 8800, 9250 and 9410 , respectively, with a growth rate of $22.62 \%, 12.30 \%,-1.68 \%, 5.11 \%$ and $1.73 \%$, respectively (United States of America Department of Agriculture, 2013).

Thus, growth in maize production and utilization has been driven by the rapidly increasing demand for maize as livestock feed, industrial food and non-food products (Abalu, 1999). Maize is used for livestock feeds in Nigeria for the past two decades and this has been increasing largely due to sharp increase in the demand for livestock and poultry products.

The demand for maize outstrips the supply, to bridge this gap, resources must not only be devoted to maize production but also be efficiently utilized. It is against this background that the research work attempts to examine resource use efficiency in maize production in Yola North Local Government Area of Adamawa State.

\section{MATERIALS AND METHOD \\ Sampling Procedure}

The sampling frame for this study is made up of all maize producers spread across six Area Councils of Yola North, namely: Doubeli, Demsawo, Jambutu, Shinko, Nassarawo and Damilu. These six areas are the highest maize producing areas in the LGA. Hence they were purposively selected. However, respondents were selected proportionate to the numbers of maize farmers in the area councils. This gave a total sample size of 120 maize farmers used for the study out of 364 total numbers of farmers. This gave a sampling percentage of 33 .

\section{Data Source and Collection}

The study employed only primary sources of data. The primary source involved the use of questionnaires as an instrument of data collection from sampled maize farmers. Variables captured included inputs used by farmers and outputs obtained.

\section{Analytical Techniques \\ Production Function Analysis}

In order to determine the exact nature/pattern of the relationship between the dependent and the independent variables, the contribution of the various inputs used by the farmers to output and in order to identify those variables that have statistically significant effects on the output, the output of maize was regressed on the farm size, seed, family labour, hired labour, herbicide and fertilizer used. Four functional forms were fitted for the regression. These were the linear, exponential, semi-log and double $\log$ functional forms. The choice of functional form to be fitted as the lead equation was based on the number of significant variables, the signs of the coefficients and the value of the adjusted coefficient of multiple determination. The double log functional form was selected however due to its conformation to a priori economic expectations.

The functional forms fitted were:

Linear $Y=b_{0}+b_{1} X_{1}+b_{2} X_{2}+b_{3} X_{3}+b_{4} X_{4}+$ $\mathrm{b}_{5} \mathrm{X}_{5}+\mathrm{b}_{6} \mathrm{X}_{6}+\mathrm{e}_{\mathrm{t}}$

Semilog $Y=b_{0}+b_{1} \ln X_{1}+b_{2} \ln X_{2}+b_{3} \ln X_{3}+$ $b_{4} \ln X_{4}+b_{5} \ln X_{5}+b_{6} \ln X_{6}+e_{t}$

Exponential In $Y=b_{0}+b_{1} X_{1}+b_{2} X_{2}+b_{3} X_{3}+$ $\mathrm{b}_{4} \mathrm{X}_{4}+\mathrm{b}_{5} \mathrm{X}_{5}+\mathrm{b}_{6} \mathrm{X}_{6}+\mathrm{e}_{\mathrm{t}}$

Double-log In $\mathrm{Y}=\mathrm{b}_{0}+\mathrm{b}_{1} \ln \mathrm{X}_{1}+\mathrm{b}_{2} \ln \mathrm{X}_{2}+$ $b_{3} \ln X_{3}+b_{4} \ln X_{4}+b_{5} \ln X_{5}+b_{6} \ln X_{6}+e_{t}$

The regression model for maize production is shown below:

$Y=f\left(X_{1}, X_{2}, X_{3}, X_{4}, X_{5}, X_{6}\right)$

Where $Y$ is output in $\mathrm{kg}$

$\mathrm{X}_{1}=$ Farm size in hectares

$\mathrm{X}_{2}=$ Quantity of seed in $\mathrm{kg}$

$\mathrm{X}_{3}=$ Family labour in mandays

$\mathrm{X}_{4}=$ Hired labour in mandays

$\mathrm{X}_{5}=$ Quantity of herbicide in litres

$\mathrm{X}_{6}=$ Quantity of fertilizer in $\mathrm{kg}$

$\mathrm{e}_{\mathrm{i}}=$ error term.

\section{Determining Technical Efficiency of Resource Use}

The elasticity of production which is the percentage change in output as a ratio of a percentage change in input was used to calculate the return to scale which is a measure of firm's success in producing maximum output from a set of inputs (Taru, Lawal and Tizhe, 2011).

$\mathrm{EP}=\mathrm{MPP} / \mathrm{APP}$

Where:

$\mathrm{EP}=$ elasticity of production

MPP = marginal physical product

APP $=$ average physical product

If

$\sum E P=1:$ constant return to scale

$\sum \mathrm{EP}<1$ : decreasing return to scale

$\sum \mathrm{EP}>1$ : increasing return to scale

\section{Measures of Resource Use Efficiency}

Efficiency measurement has received considerable attention from both theoretical and applied economists. From a theoretical point of view; there has been a spirited exchange about the relative importance of the various components of firm efficiency (Taru, et al., 2008; Taru, 2011). Measuring efficiency from 
an applied perspective is significant because it provides the first step in a process that might lead to substantial resource savings, which has important implications for both policy formulation and firm management (Bravo and Rieger, 1991). However, the measures of resource use efficiency used are as follows.

\section{MVP/MFC Ratio}

The most widely used measure of resource use efficiency is the MVP/MFC ratio. The MVP/MFC is more reliable and statistically testable since it could be obtained from the coefficient estimates (Alimi, 2000). Likewise, the process generates the coefficient estimates based on the assumption that all other factors are held constant and each estimate is more valid measure of that factor alone while effects of other factors are fixed (Ayanwale, 1995). The MVP measures the change in the value of output as variable resources are changed by one unit. Thus, it forms a basis for policy decision with regards to resource use. Positive value of MVP simply means that output could be increased by using more of the variable resource (Omotesho, et al., 1993). However, the extent of increase or otherwise were determined by comparing MVP with opportunity cost of MFC (Adesimi, 1982; Alimi, 2000). The difference between the MVP and the acquisition cost of the input determines the level of adjustment in the variable resources so as to attain economic optimum (Ogunfowora and Olayide 1975). Theoretically, a variable resource is optimally utilized when ratio of MVP to MFC is unity. A ratio of less than unity is interpreted to mean that variable resources are being over utilized, while a ratio greater than unity is an indication of resource underutilization (Adesimi, 1982; Ayanwale, 1995; Abdul, Bello and Kushawela, 2001).

The following ratio was used to estimate the relative efficiency of resource use (r)

$\mathrm{r}=\mathrm{MVP} / \mathrm{MFC}$

Where:

$\mathrm{MFC}=$ cost of one unit of a particular resource MVP = value added to maize output due to the use of an additional unit of input,

calculated by multiplying the MPP by the price of output. i.e. MPPxi x Po

\section{Decision rule}

If $r=1$, resource is efficiently utilized,

If $r>1$, resource is underutilized while

If $\mathrm{r}<1$, resource is overutilized. Economic optimum takes place where MVP $=$ MFC. If $r$ is not equal to 1 , it suggests that resources are not efficiently utilized. Adjustments could therefore, be made in the quantity of inputs used and costs in the production process to restore $r=1$.

\section{RESULTS AND DISCUSSION Input - Output Relationship Production Function Analysis}

The result of the analysis carried out using different functional forms revealed that Cobb Douglass gave the best fit. It was therefore chosen as the lead equation, based on the magnitude of coefficient of multiple determinations $\left(\mathrm{R}^{2}\right)$, the number of significant independent variables and the conformity of the signs of the significant regression coefficients to a priori theoretical expectation. The coefficient of multiple determinations $\left(\mathrm{R}^{2}\right)$ indicates the percentage of variation in the output, which was explained by change in the variable inputs, included in the fitted regression equation. From Table 2, the value of coefficient of multiple determinations was 0.84 which indicated that $84 \%$ of the variation in the output of maize was explained by the model. Other factors not included in the model might be responsible for the remaining $16 \%$ of the yield variations in maize production. The F- statistics was statistically significant at $(\rho<0.10)$ which implies that the independent variables adequately explained the dependent variable.

The T-values showed that farm size in hectare, seed in $\mathrm{kg}$ and fertilizer in $\mathrm{kg}$, were significant and had a positive influence on output (Y) but other variables were not significant. This indicated that taken together the explanatory variables in the models significantly explained variation in the output. The regression coefficient of each variable revealed the extent to which variable have their effects on the dependent variable.

Table 2 shows the regression coefficients with respect to each of the explanatory variables, their standard errors and T-values. The coefficients of farm size, seed, family labour, herbicide and fertilizer were positive, indicating that an increase in any of the variables holding others constant will lead to increase in the total output. Hired labour was found to be inversely related to the output but not significant, indicating that an increase in hired labour holding others constant will lead to reduction in the total output. 
Table 1: Relative Contribution of family and hired labour to key operations

\begin{tabular}{llll}
\hline Operations & Family labour & Hired labour & Total labour \\
\hline (manday/ha) & (manday/ha) & (manday/ha) & \\
Land Preparation & $8.70(28.69)$ & $3.20(23.44)$ & $11.90(27.06)$ \\
Planting & $2.12(6.99)$ & $0.40(2.93)$ & $2.52(5.73)$ \\
Fertilizer application & $1.60(5.28)$ & $0.55(4.03)$ & $2.15(4.89)$ \\
Weeding & $12.50(41.23)$ & $4.80(35.16)$ & $17.30(39.35)$ \\
Spraying & $1.30(4.29)$ & $2.50(18.31)$ & $3.80(8.64)$ \\
Harvesting & $4.10(13.52)$ & $2.20(16.12)$ & $6.3(14.33)$ \\
Total & 30.32 & 13.65 & $43.97(100)$ \\
& $\mathbf{6 8 . 9 6}$ & $\mathbf{3 1 . 0 4}$ & \\
\hline
\end{tabular}

Source: Field Survey, 2011.

Table 2: Results of regression analysis from double log function

\begin{tabular}{|c|c|c|c|}
\hline Variables & Regression Coefficient & Standard Errors & t-values \\
\hline Land $\left(\mathrm{X}_{1}\right)$ & 0.750 & 0.118 & $7.183^{* * *}$ \\
\hline Seed $\left(X_{2}\right)$ & 0.065 & 0.104 & $0.761 * *$ \\
\hline Family Labour $\left(\mathrm{X}_{3}\right)$ & 0.027 & 0.034 & $0.516^{\mathrm{NS}}$ \\
\hline Hired labour $\left(\mathrm{X}_{4}\right)$ & -0.014 & 0.030 & $-0.279^{\mathrm{NS}}$ \\
\hline Herbicide $\left(\mathrm{X}_{5}\right)$ & 0.032 & 0.043 & $0.410^{\mathrm{NS}}$ \\
\hline Fertilizer $\left(\mathrm{X}_{6}\right)$ & 0.152 & 0.062 & $1.865^{*}$ \\
\hline Constant & 0.429 & $2.161 * * *$ & \\
\hline$\sum \mathrm{bi}$ & 1.012 & & \\
\hline $\mathrm{R}^{2}$ & 0.84 & & \\
\hline F- Value & 65.13 & & \\
\hline$=$ signifi & robability & & \\
\hline$=$ signifi & robability & & \\
\hline$=$ signifi & probability & & \\
\hline$=$ not sig & & & \\
\hline
\end{tabular}

As expected a priori, all the regression coefficients had the expected signs except hired labour, which implied that all the inputs contributed positively to output of maize. However, farm size, seed and fertilizer were significant at $1 \%$ and $5 \%$. This implied that farm size, seed and fertilizer are directly proportional to output. The high coefficient of determination showed that the independent variables explain the dependent variable. The total elasticity of the inputs used under maize production was 1.002, an indication of increasing returns to scale.

The other regression results were presented in Appendix B.

\section{Resource Use Efficiency}

According to Kohler (1982), the concept of efficiency is concerned with relative performance of the processes used in transforming inputs into output. In order to determine the resource use efficiency, the marginal physical product (MPP) and marginal value product (MVP) for each significant variable was determined and they were divided by the marginal factor cost (MFC) which is the unit cost of each input.

For double log, the model is differentiated first to obtain the marginal physical product. (The coefficient for each variable input from Table 1 was multiplied by the mean of the output and then divided by the mean of each variable unit). Marginal product
(MP) of each variable input for Cobb Douglass production function is given by $\mathrm{b}_{1} \mathrm{Y} / \mathrm{X}_{1} \mathrm{Py}$.

Where $b_{1}$ represents the regression coefficient for the variable input, $\mathrm{X}_{1}$ and $\mathrm{Y}$ represent, the value of variable input and the dependent variable respectively, and Py represents the price of output (Alimi, 2000), while for the marginal value product (MVP) the marginal physical product (MPP) was multiplied by the unit price of the output. The marginal factor cost (MFC) of input was taken to be either the market price if purchased from competitive input market or geometric mean values of the input costs, or depreciation if durable assets.

In order to determine whether or not the inputs have been used efficiently, the marginal value product (MVP) was divided by the marginal factor cost (MFC) i.e. the unit price of each input. A given resource is said to be efficiently utilized if the marginal value product is just sufficient to offset its acquisition price (unit price). This can provide guides to farmers on how to apportion their resources to maximize profit. Economic theory states that a firm maximizes its profit with respect to an input if the ratio of it MVP to its MFC is equal to one (Kay, 1981). A ratio less than unity show over utilization of the resource and profit would be increased by decreasing the quantity of that input used. A ratio greater than unity indicates underutilization of the input and increasing the rate of use of that input will increase the level of profit 
of the firm, and when the ratio is equal to one (i.e. unity), the resources are said to be efficiently utilized (i.e. MVP=MFC)

Table 6 shows the result of the marginal analysis of resource use of maize production based on Cobb-Douglass function as lead equation. The result showed that maize producers underutilized some of the resources.

$\mathrm{MPPx}_{1}=$ marginal physical product of $\mathrm{x}_{1}$, which is computed as $\mathrm{MPP}=\underline{\mathrm{b}}_{1} \underline{\mathrm{Y}} \mathrm{X}$

Where,

$\mathrm{b}_{1}=$ regression coefficient associated with the independent variables
$\mathrm{X}=$ Arithmetic mean of the independent variables

$\mathrm{Y}=$ Arithmetic mean of output

The results in Table 6 showed that the ratio of the marginal value product (MVP) to marginal factor cost (MFC) for land, seed, herbicide and fertilizer were $18.47,3.17,7.73$ and 1.58, respectively. The implication of this result is that these resources were underutilized, meaning farmers will earn higher returns from their production if they increased the use of land, seed, herbicide and fertilizer. The results

Table 3: Computation of marginal physical product (MPP)

\begin{tabular}{llcc}
\hline Variable Factors & $\mathbf{X}$ & $\mathbf{b}_{\mathbf{1}}$ & MPP \\
\hline & & & \\
Land $\left(\mathrm{X}_{1}\right) \mathrm{ha}$ & 2.55 & 0.750 & 274.1 \\
Seed $\left(\mathrm{X}_{2}\right) \mathrm{kg}$ & 19.63 & 0.065 & 3.09 \\
Family labour $\left(\mathrm{X}_{3}\right)$ man day & 30.32 & 0.027 & 0.83 \\
Hired Labour $\left(\mathrm{X}_{4}\right)$ man day & 13.65 & -0.014 & -0.96 \\
Herbicide $\left(\mathrm{X}_{5}\right)$ Litre & 2.6 & 0.32 & 114.7 \\
Fertilizer $\left(\mathrm{X}_{6}\right)(\mathrm{kg})$ & 204.19 & 0.152 & 0.69 \\
$\quad \mathrm{Y}$ & 932 & & \\
\hline
\end{tabular}

Source: Field Survey, 2011.

Table 4: Computation of marginal value product (MVP)

\begin{tabular}{lccc}
\hline Variable Factors & MPP & & Unit of output MVP \\
\hline Land $\left(\mathrm{X}_{1}\right)$ ha & 274.1 & 64 & 17542.4 \\
Seed $\left(\mathrm{X}_{2}\right) \mathrm{kg}$ & 3.09 & “ & 197.8 \\
Family labour $\left(\mathrm{X}_{3}\right)$ man day & 0.83 & “ & 53.12 \\
Hired Labour $\left(\mathrm{X}_{4}\right)$ man day & -0.96 & “ & -61.44 \\
Herbicide $\left(\mathrm{X}_{5}\right)$ Litre & 114.7 & “ & 7340.8 \\
Fertilizer $\left(\mathrm{X}_{6}\right)(\mathrm{kg})$ & 0.69 & “ & 44.2 \\
\hline So
\end{tabular}

Source: Field Survey, 2011.

Table 5: Computation of marginal factor cost (MFC)

\begin{tabular}{|c|c|c|}
\hline $\begin{array}{c}\text { Variable Factors } \\
\text { Unit } \\
\end{array}$ & Unit price $(\mathbf{N})$ & \\
\hline Land $\left(\mathrm{X}_{1}\right)$ ha & $\mathrm{Ha}$ & 950 \\
\hline Seed $\left(X_{2}\right) \mathrm{kg}$ & $\mathrm{kg}$ & 62.5 \\
\hline Family labour $\left(\mathrm{X}_{3}\right)$ man day & Man day & 62.5 \\
\hline Hired Labour $\left(\mathrm{X}_{4}\right)$ man day & Man day & 62.5 \\
\hline Herbicide $\left(X_{5}\right)$ Litre & Litre & 950 \\
\hline Fertilizer $\left(\mathrm{X}_{6}\right)(\mathrm{kg})$ & $\mathrm{kg}$ & 28 \\
\hline
\end{tabular}

Source: Field Survey, 2011.

Table 6: Determination of resource use efficiency from ratio of MVP/MFC

\begin{tabular}{|c|c|c|c|c|}
\hline Variable & MVP & MFC & MVP/MFC & Efficiency \\
\hline Land $\left(\mathrm{X}_{1}\right)$ ha & 17542.4 & 950 & 18.47 & underutilization \\
\hline Seed $\left(X_{2}\right) \mathrm{kg}$ & 197.8 & 62.5 & 3.17 & under utilization \\
\hline Family labour $\left(\mathrm{X}_{3}\right)$ man day & 53.12 & 62.5 & 0.85 & Over utilization \\
\hline Hired Labour $\left(\mathrm{X}_{4}\right)$ man day & -61.44 & 62.5 & -0.98 & Over utilization \\
\hline Herbicide $\left(\mathrm{X}_{5}\right)$ Litre & 7340.8 & 950 & 7.73 & underutilization \\
\hline Fertilizer $\left(\mathrm{X}_{6}\right)(\mathrm{kg})$ & 44.2 & 28 & 1.58 & underutilization \\
\hline
\end{tabular}

Source: Field Survey, 2011. 
agreed with other findings like Dakyong (1996), Alimi (2000) and Alabi, Adebayo, Akinyemi, Olumutiwa and Adewuyi (2005) and which disclosed that land, seed and fertilizer were underutilized. The twin issues of availability and affordability could have necessitated the underutilization of fertilizer and herbicide (Tanko \& Onyenweaku 2006), while the underutilization of farm size may be due to fragmentation of farm land due to inheritance.

From Table 6 the marginal value product of farm size was $\$ 17,542.40$. This means that an increase by 1 hectare will increase the total product of maize by $\sharp 17,542.40$. The MVP/MFC ratio showed underutilization, increase in farm size will equally increase profit, so the use of farm size should be increased. The underutilization of farm size may be due to fragmentation of farm land due to inheritance. Seed was underutilized since all of the farmers planted less than recommended seed rate of $23 \mathrm{~kg} / \mathrm{ha}$. Therefore increase in seed rate will increase the profit by 197.80/ha. Family labour was over-utilized because the farmer uses his immediate family member for labour which is considered to be free and readily available. Decrease in family labour will lead to increase in the profit by $\$ 53.12$. Hired labour has negative efficiency ratio meaning that increase in the use of such resource will lead to reduction in the profit by $\$ 61.44$.The over use of labour can be attributed to credit farming (Jinga) which is an agreement to pay back after harvesting. The use of this resource should be reduced to increase profit. High cost of herbicide made it to be underutilized and increase in the use of herbicide will increase the profit by $\$ 7340.80$.Fertilizer was underutilized because of the high cost and availability of such resources and increase in use of fertilizer will increase profit by $\$ 44.20$

\section{Elasticity of Production and Return to Scale}

The elasticity of production measures the responsiveness of output to a change (increase or decrease) in input. The objective here is to determine the degree to which the inputs considered in the regression analysis affected the output. The estimated values are shown in Table 7. The elasticity of production was greater than 1 for all the input used. Analysis of the data gave an estimated return to scale of 1.012, implying that the farmers produced at increasing returns to scale. The production is increasing at an increasing rate, if all inputs included in the model were increased by 1 percent, output too, would increase by 1.012 percent. Table 7 further revealed that the elasticity of production with respect to the various inputs indicated that farm size was the major input to which output was more responsive in the study area.

Table 7: Estimated elasticity of production and return to scale

\begin{tabular}{ll}
\hline Variables & Coefficient of elasticity of production \\
\hline Farm size $\left(\mathrm{X}_{1}\right)$ & 0.750 \\
Seed $\left(\mathrm{X}_{2}\right)$ & 0.065 \\
Family Labour $\left(\mathrm{X}_{3}\right)$ & 0.027 \\
Hired labour $\left(\mathrm{X}_{4}\right)$ & -0.014 \\
Herbicide $\left(\mathrm{X}_{5}\right)$ & 0.032 \\
Fertilizer $\left(\mathrm{X}_{6}\right)$ & 0.152 \\
\hline Return to scale & \\
\hline
\end{tabular}

Source: Field Survey, 2011.

\section{Problems of Maize Production in the Study Area}

Table 8: Technical and socio-economic problems encountered by the respondents

\begin{tabular}{llll}
\hline Problems & Frequency & Percentage (\%) & Rank order \\
\hline Financial constraint & 46 & 38.3 & 1 \\
Lack of improved seed & 30 & 25 & 2 \\
Inadequate fertilizer & 24 & 20 & 3 \\
Inadequate extension service & 12 & 10 & 4 \\
Land tenure and acquisition & 8 & 7 & 5 \\
Total & $\mathbf{1 2 0}$ & $\mathbf{1 0 0}$ & \\
\hline
\end{tabular}


Table 8 showed that lack of adequate fund was the most serious problem being faced by respondent maize farmers as indicated by $38.3 \%$ of them. This inhibits the ability of farmers in expanding their production beyond the smallscale levels. Unavailability of credit affects input availability and efficiency adversely. Besides the quantities of inputs used, the timing of input used is also important in determining yields. The farms that have access to credit may be able to arrange production at the best timing (Aye \& Oboh, 2006). This explains why most of the farmers cultivated less than two hectare of land.

Another problem was lack of improved seed variety as shown by $25 \%$ of the respondents which made them rely heavily on the use of local variety. However, $20 \%$ of the respondents pointed out insufficient supply of fertilizer as the problem. They added that fertilizer was not usually supplied at the right time. Owing to this, farmers left their farm work and made multiple trips to distant markets in search of a few bags of fertilizer. In most cases they could not get any to buy. Fertilizer is often scarce and costly because of ineffective government agencies, poor transport system and restriction on private sector fertilizer marketing.

Although access to extension service enables the farmers to acquire technical knowledge as well as have access to improved production technology, the service is also not adequately provided to them as observed by 12 or $10 \%$ of the farmers. Land tenure and acquisition problem was the least in the hierarchy of the problems enumerated by the respondents.

\section{REFERENCES}

Abalu, G. I. (1999). Policy Issues in Maize Research and Development In SubSaharan Africa in the next Millennium, in B. B. Apraku, M. O. Akoroda, M. Ouedraogo, F.M. Quin (eds). Impact, Challenges and Prospects of Maize Research and Development in West and Central Africa, Proceeding of a Regional Maize Work Shop, 4-7 May, IITACOTONOU, Benin Republic.

Abdul, Z.H., Bello, M. \& Kushawela, S. (2001). "Efficiency of Rural Resource Utilization for Sustainable Irrigated Agriculture in Nigeria, In K.M. Baba, I. Mohammed, U. B. Kyogwon and H.M. Bello (Eds), Rural Resources and Sustainability, Proceedings of $9^{\text {th }}$ Annual Conference at Nigeria Sociology Association, Held at the UDU, Sokoto, Between $5^{\text {th }}-8^{\text {th }}$ March, 1996, pp. 39-43.
Adepoju, S.O. (2007). An Analysis of Industrial Demand for Maize in three Selected States of Nigeria, In: Shola, O.A and P.B. Okuneye (eds). Technology and Agricultural Development in Nigeria, Proceeding of $20^{\text {th }}$ Annual Conference of Farm Management Association of Nigeria (FAMAN), Forestry Research Institute of Nigeria, Federal College of Forestry Jos, Plateau State, 18-21 ${ }^{\text {st }}$ Sept, 2006.

Adesimi, A.A. (1982). "Economics of Research in Maize Production in Farm Settlement Schemes of Western Nigeria", Ife Journal of Agriculture, 4(162): 118131.

Alabi, O. O., Adebayo, O., Akinyemi, O., Olumuyiwa, S.A. and Adewuyi, G. (2005). Resource Productivity and Returns on Maize Production in Kauru Local Government Area of Kaduna State, International Journal of Food and Agricultural Research, 2(1\&2)(InPress)

Alimi,T. (2000). "Resources Used Efficiency in Food Crop in Oyo State". Journal of Agriculture and Environments (1): 1-7.

Ayanwale, A.B. (1995). Resource Used Efficiency in Cassava Processing in Oyo, Nigeria Ife Journal of Agriculture. 16/17: .123-135.

Aye, G.C. \& Oboh, V. U. (2006). The Resource Use Efficiency in Rice Production in Benue State, In: Shola, O.A and P.B. Okuneye (eds). Technology and Agricultural Development in Nigeria, Proceeding of $20^{\text {th }}$ Annual Conference Farm Management Association of Nigeria (FAMAN), Held at Forestry Research Institute of Nigeria, Federal College of Forestry Jos, Plateau State, $18-21^{\text {st }}$ Sept.

Bravo-Ureta, B.E., Rieger, L. (1991). "Dairy Farms Efficiency Measurement using Stochastic Frontiers and Neoclassical Duality", American Journal of Agricultural Economics, 73: 421-428.

Dakyong, T. G. (1996). An Economic Analysis of Acha Production and Marketing in Plateau State. B.Sc. Project, Department of Agricultural Economics and Extension, Usmanu Danfodiyo University, Sokoto. P. 94.

FAO, (2006). FAOSTAT, Food and Agricultural Organization, Food Production Data, Nigeria http://faostat.fao.org/site/336/Deskto pDefault.aspx? Page ID=336. 
Farrel,M.J. (1957). “The Measurement of Productive Efficiency" Journal of Royal Statistical Society Sreies A (General). Part III 120: 253 - 280.

Iken, J.E. and N.A. Amusa, (2004). Maize Research and Production in Nigeria. African Journal of Biotechnology, 3(6): 302-307.

Kohler, H. (1982). Intermediate Macroeconomics, Foreman and Co. Glenview, Illinois, USA. Pp.43-52.

Ogunbodede, B.A., and Olakojo, S.A. (2001). Development of Sriga asiastica Tolerant HybridMaize (Zea mays L.) Varieties. Tropical Agriculture Research and Extension, 4(1), 20.

Ogunfowora, E., and Olayide, M. S. (1975). Resource Productivity in the Tradition Farming: a Case of Four Agricultural Division in Kwara State of Nigeria, Journal of Rural Economics and Development 9(2):119-131.

Ojo, S.O., (2000). Factor Productivity in Maize Production in Ondo State, Nigeria. Applied Tropical Agriculture, 15(1): 57-63.

Okuneye, P.A., Afolami, C.A. and Momoh, S. (1995). Stimulating Growth in Agricultural Guarantee Scheme (ACGS). A Paper Presented at the Annual Conference of Agricultural Credit Officers of the Central Bank, October 23rd to 26th.
Omotesho, O.A., Olufe, J. and Aladeji, S.O. (1993). "Resource Productivity in Food Crop Production in Some Selected Villages of Kwara State, Nigeria," Ife Journal of Agriculture 14 and 15: .9097.

Taru, V.B., Kyagya, I.Z., Mshelia, S.I. and Adebayo, E.F. (2008). Economic Efficiency of Resource Use in Groundnut production in Adamawa State of Nigeria, World Journal of Agricultural Sciences 4: 896-900.

Taru, V.B., Lawal, H. \& Tizhe, I. (2011). Technical Efficiency of Sole Cowpea Production in Adamawa State, Nigeria: A Cobb-Douglas Stochastic Frontier Function. Journal of Economics and Internal Finance 3(8):, 504-507.

Tanko, L., and C. E. Onyenweaku (2006). Farm Enterprise: Combinations and Resource Use among Small Holder Farmers in Bunza Agricultural Zone Kebbi State, In: Shola, O.A and P.B. Okuneye (eds). Technology and Agricultural Development in Nigeria, Proceeding of $20^{\text {th }}$ Annual Conference of Farm Management Association of Nigeria (FAMAN), Held at Forestry Research Institute of Nigeria, Federal College of Forestry Jos, Plateau State, 18-21 ${ }^{\text {st }}$ Sept.

Kay, R.D. (1981). Farming Management Planning Control and Implementation. McGraw-Hill, New York,350pp. 